\title{
A TELJESSÉG IGÉNYÉVEL
}

Berend T. Iván, az American Academy of Arts and Sciences és a British Academy tagja, nem tartozik azok közé, akik egy szép cím vagy rang elnyerése után kényelmesen hátradőlnek a karosszékben. Kilencvenedik életévén túl is változatlan alkotóerővel, a világ iráni kíváncsisággal és az új meglátásokra fogékonyan értelmezi a történéseket. Bár jó három évtizede Amerikában él, lélekben sosem szakadt el Magyarországtól és Európától. Munkáinak tárgya továbbra is az összehasonlító európai gazdaságtörténet, amit esszékötetek, életrajzok és nem utolsósorban publicisztikák is kiegészítenek. Joggal mondhatjuk: kinn is van, meg benn is van.

Az elmúlt évek tudományos termése az utóbbi két évszázad társadalmi és gazdasági fejlődésének újraértelmezésére törekedett, méghozzá a globális folyamatok összefüggésében. A most ismertetett kötet tárgya az Európai Unió fejlődése, amit a populista és nacionalista törekvésekkel folytatott szakadatlan küzdelem jellemez. A szerző nem tekinti az EU-t sem szükségszerünek, sem öntörvényeit követő szervezetnek. Már az első pillanattól - sőt az előzménynek tekinthető Európai Szén- és Acélközösségtől és az Európai Védelmi Uniótól - kezdve a tágabb világ kihívásaira próbált meg válaszolni. Inkább sikerrel, mint sikertelenül.

A kéziratban 1100 oldalnyi áttekintést nem lehet a szokásos módon recenzálni. A kifejtés sajátosságaként kiemeljük, hogy a szerző rendre az eszmék története, a gazdasági érdekek, a politikai megfontolások és a világpolitika egymásra hatásában mutatja be az egyes időszakok és területek fejlődését. Sok újat mond azáltal, hogy rendre az elsődleges forrásokig megy vissza, Sztálin távirataitól az amerikai követségek titkos iratain át az egy-egy időszakban kulcsszerepet játszó személyek visszaemlékezéseiig, az újabb statisztikai elemzésektől a tanácsadó intézetek belső anyagaiig terjedően. A kifejtés mindig alapos, de sosem terjengős, és az egyes meghatározó tények rendre új megvilágításba helyeznek olyan ismert eseményeket is, mint a német egység vagy éppen a britek kilépése.

Ebben a nagy összegzésben - a figyelemre nagyon is méltó részleteken túl - a hangsúlyok és az összkép kontúrjai adják a különlegességet. A költségvetési adok-kapok, a sajtón keresztüli üzengetés zajában elfelejtődik az a hallatlan szellemi és lelki erőfeszítés, ami a háborús megosztottság végleges meghaladását eredményezte. Elfelejtődik az, hogy az Egyesült Államok nyomása, sőt intrikái nélkül a németek és a franciák inkább fölfalták volna egymást, mint nem. Háttérben marad az, hogy az Unió fejlődése mind a mai napig egyensúlyoz a Jean Monnet képviselte ágazati politikákra épülő, fokozatos közelítés és a politikában Walter Hallstein, majd Jacques Delors, a tudományban Balassa Béla képviselte átfogó, funkcionalista közelítés között.

A negyedik rész alaposan érvel amellett, hogy Európa nem tudott jó válaszokat adni a neoliberális globalizáció kihívásaira, és végeredményben csak a nemzet- 
közivé váló vállalatbirodalmak érdekérvényesítése okán nem akadt el az integráció elmélyítésének terve a 80 -as évek második felében. Érdekes részletekkel teli - és sokak számára talán vitatható - az ötödik rész ama gondolatmenete, hogy a kellő megalapozás - és belső reformok - híján végrehajtott állandó bővítés végeredményben közvetlen okává vált az integrációs projekt elakadásának, majd felhígulásának a 2005-öt követő másfél évtizedben. Egyfelől: az EU képtelenné vált szélesebb szomszédságának megbékítésére és az európai távlat révén a demokratikus átalakulás megalapozására. Másfelől: a belső reformok elakadása indokolttá tette azt az álláspontot, ami szerint kevéssé fejlett és a demokrácia iránt kevés fogékonyságot mutató szomszédokkal bővülni veszélyes.

A hatodik rész a 2008 óta eltelt időt - beleértve a koronavírus-járvány okozta válságot - a folytonos elöre menekülés pályájaként jellemzi. S való igaz: a kicsit nagyvonalúan költségvetési és bankuniónak nevezett megoldások, az uniós válságkezelő alapok rendje és a - szerzőnk által nagyra értékelt - Európai Központi Bank korlátlan likviditásbővitési programja együttesen elhozta az Unió nemzetek fölötti vonásainak megerősödését. Eközben a politika végig a kormányköziséget erőltette. Nem is meglepő, hogy a hetedik rész témájaként az elit és a népesség közti szakadék, az Uniót elvető jobb- és baloldali populizmus térnyerése lett. Igaz, e folyamatnak a 2017-2020 közti események határt szabtak, ugyanakkor az sem kétséges, hogy legitimáció híján a mélyülési tervek sem lesznek megvalósíthatók. A többéves költségvetés és az újjáépítési alap, a környezetvédelmet a tengelybe állító „zöld megállapodás” és az uniós szervek hatásköre ügyében jelenleg is folyó viták aligha érnek egyhamar véget oly módon, hogy az minden szereplő számára elfogadható eredménnyel járjon. A mélyülést a - kilencedik fejezetben külön taglalt - autokratikus kihívás, a török, orosz és kínai erők nyílt és rejtett bomlasztó tevékenysége csak erősítheti.

Milyen mérleget lehet vonni? A záró fejezteben ismét előjön a történész énje: az egy före jutó nemzeti termék tekintetében térségünk 2019-ben ugyanúgy a nyugat-európai 36\%-án állt, mint 1990-ben, míg 1913-ban 50 és 1870-ben 54\% volt ugyanez az értek. Igaz, sok régió fölzárkózott, az IT-forradalom és a nemzetközi vérkeringésbe történt bekapcsolódás jobbá tette sok ember életét, de a várt nagy utolérés álom maradt, másfél évszázad múltán is.

Az előadottakkal reményeim szerint sikerült meggyőznöm az érdeklődőket: olyan kötetről van szó, ami tíz vagy húsz esztendő múlva is könyv lesz. Egyes megállapításaival talán vitázunk, másokra azt mondjuk: sose hittem volna. De végig olvasmányos, jól fölépített, számos újdonságot tartalmazó, igazi nagy öszszegző mü született.

(Berend T. Iván: The Economics and Politics of European Integration. Abingdon: Routledge, 2021, 288 o.)

Csaba László az MTA és az Academia Europaea (London) rendes tagja 